\title{
A Literature Review on Organization Culture and Corporate Performance
}

\author{
Cui Xiaoming (Corresponding author) \\ School of Management, Fudan University \\ Shanghai, China \\ E-mail:cui_xiaoming@msn.cn \\ Hu Junchen \\ School of Management, Fudan University \\ Shanghai, China \\ E-mail:junchenhu@fudan.edu.cn
}

Received: December 19, 2011 Accepted: January 19, 2012 Published: March 15, 2012

doi:10.5430/ijba.v3n2p28

URL: http://dx.doi.org/10.5430/ijba.v3n2p28

This research is supported by the State social science fund: Strategy of Rejuvenating the country through science and education (No. 07\&ZD042). (Sponsoring information)

\begin{abstract}
From 1980s, there are more and more studies about organization culture. And in Chinese studies and practices, we pay much attention to the culture due to the direct relationship between the organization culture and corporate performance, which we can be convinced by some academic papers. But there are some limitations in the study. This paper would like to give a literature review about organization culture and corporate performance. Meanwhile, we would give some suggestions about the further study.
\end{abstract}

Keywords: Organization Culture, Corporate Performance, Organization Commitment

From the perspective of management, the organization culture has been coming to our research and practice in 1980s after experience management and scientific management (Kotter john P. \& Heskett, 1992). And there might be two main branches for the research on the organization culture--one on the measure of the organization research (Saxton,1983; Coake \& Lafferty, 1989, Hofstede, 1990; Dension, 1995) and the other on the relationship between the organization culture and corporate performance (Barney, 1986; Kotter john P. \& Heskett, 1992; Gordon \& Tomaso,1992). And what we most concern must be the latter one, while the measurement is just a tool. Fortunately, lots and lots of studies have inspected and verified the positive relationship between the organization culture and corporate performance (Gordon, 1985; Gordon \& Tomaso, 1992; Kotter john P. \& Heskett, 1992; Torvald, Svein and Einar, 2005; Ken W. Parry \& Sarah B. Proctor-Thomson, 2003). For the most part, however, these arguments have been conceptual and anecdotal or have been case studies without formal measurement of either performance or culture (Gordon \& Tomaso, 1992). This paper will examine the relationship between the organization culture and corporate performance and their mechanisms in hide, using both the qualitative methods and quantitative analysis.

Defining the organization culture is essential to the study and it will be the start of our research. In this paper, we would like to address the following issues to examine the relationship between the organization culture and corporate performance. (1) What is organization culture from the newly perspective on the past? (2) How to measure the organization culture, especially in the environment of China. (3) Which is the most fitting variable to represent the corporate performance, accounting performance, Tobin' Q, or long-term stock market performance? (4) Verifying some probable moderators or mediators, such as organization commitment, to describe the mechanisms in hide. (5) Discussion on the endogenous problem between the organization culture and corporate performance to construct the equilibrium path or the out-of-equilibrium path. (6) Some useful advice, especially from the point of sub-consciousness creatively. 


\section{Organization Culture}

From the prevalence of Japan management style (William Ouchi; Richard Tanner Pascale \& Anthony G. Athos; Thomas Peters \& Robert Waterman; Allen A. Kennedy \& Terrence E. Deal), organization culture come into prominence. But up to the present, there are various definitions for organization culture without an agreement. According to Gordon \& Tomaso (1992) and Hang-Yue Ngo \& Raymond Loi (2008), this paper simply classify the main definitions into several categories accounting their core concerns: basic assumptions (Schein, 1985, 1992), shared values (Peters and Waterman, 1982; Roland Calori \& Philippe Sarnin, 1991; Wiener \& Vardi, 1990), beliefs (Davis, 1984; Lorsch, 1985) and norms of behavior (Lepak, Takeuchi, Erhardt and Colakoglu, 2006) and other personalized claims (firm-level resource by Barney) .

The most representative point from the perspective of basic assumption is the opinion that the organization culture is 'a pattern of shared basic assumptions that the group learned as it solved its problems of external adaptation and internal integration, that has worked well enough to be considered valid and, therefore, to be taught to new members as the correct way to perceive, think, and feel in relation to those problems (note 1)'. This conception fits in well with the normalized usage of organization culture, however, it is hard to construct quantitative dimensions and items to give the organization culture a reliable and valid measurement. Just as Schein (1984) suggested, the basic assumption is something taken for granted, invisible and preconscious. To be sure, in the qualitative analysis, especially in the distinction of strong cultures and weak cultures, these claims would come in handy.

The shared values dominate the research on the organization culture from Thomas Peters \& Robert Waterman (1982). In their luminous best seller, In Search of Excellence, the authors raised the 7-S model which considered the 'Shared Value' as the key element and one of the soft factor going to sustain company's competitive advantage. As the authors suggested, the shared values is guiding concepts, fundamental ideas around which a business is built_— must be simple, usually stated at abstract level, have great meaning inside the organization even though outsiders may not see or understand them (note 2). Its meaning tell us: (1) what the organization stands for and what it believes in; (2) the organization culture would be useful in obtaining excellence due to its imitable advantages; (3) shared values can be measured from the relative value theory in the field of sociology and so on. What's more, based on their constructive contribution, many scholars inherit and development the shared phenomenon. Wiener \& Vardi (1990) defined culture as a system of shared values which produce normative pressures on members of organization. Gordon \& Tomaso (1992) consider corporate culture to be the pattern of shared and stable beliefs and values that are developed within a company across time. And Hang-Yue Ngo \& Raymond Loi (2008) claim that the organizational culture reflects the vision of a firm. Additionally, Gordon \& Tomaso (1992) hold the idea that frequency or similarity or intensity composes the "sharing", which is stimulating for the further study in the measurement of organization culture. Meanwhile, by the definition from the basic assumption by Schein $(1984,1992)$, the shared value is some aware manifestation of the basic assumption. From the above analysis, though there still lack of consistency of variables and definitions, the point of shared value would be a generally accepted belief with the phase, according to James L. Garnett, Justin Marlowe, and Sanjay K. Pandey (2008).

As to the other two opinions, beliefs and norms of behaviors, they are always found together with the shared values. For example, Kono Toyohiro (1990) thought of the organization culture as the shared values, shared thoughts, shared decision methods and shared behavioral pattern. Dension (1984) agreed that the corporate culture refers to the set of values, beliefs and behavior patterns that form the core identity of an organization. As we have learnt in the sociology, the beliefs make up of some various values and ultimately result in behavior. So the value, belief, and behavior cannot be separated. It is just as the definition drawn by Gordon \& Tomaso (1992) that the shared and stable values and beliefs together with the norms of behavior.

Of course, there would be numerous literatures which focus on the superficial symbols of organization culture. Most research put the slogans, organizational system or institution as the symbols, while some other researchers account the behavior pattern into this aspect, such as Schein (1982). Though the symbols of organization culture are visible, they are often not decipherable (Schein, 1982). Thus, this paper would like to consider the organization from the profound level, the value.

According to the previous literature, all these definitions are significant in their respective domains without contradictions (see figure 1). The basic assumption is the original resource for the organization culture, but difficult for measure. The symbols would be visible and audible; however, they need professional skills, hard to master, to decipher them into the phase of culture. So this paper would like to focus on the shared value to conduct the research on the relationship between the organization culture and corporate performance. The shared value is the most accepted aspect in the research of organization culture due to its meaning and measurement. 
$<$ Figure 1 about here $>$

The above model, Water lily model (Edgar H. Schein, 1990), arrives at the same end by different means or roads from Geert Hofstede (1990). Hofstede (1990) measured the organization culture through qualitative and quantitative method from the following four hierarchies: value, ceremony, hero and symbols. And in this paper, we define the organization culture as the shared and stable values, beliefs, and norms of behaviors for constructing the unique competitive advantages generated in the company across time.

\section{Organization Culture and Corporate Performance}

\subsection{Corporate Performance}

The unique question about the corporate performance is the problem of variable selection, that is, which variable could measure the true corporate performance or value well. Still, the literature is even more ambiguous about the measurement of corporate performance. According to all the literatures, especially borrow idea from the typical work by Benjamin E. Hermalin and Michael S. Weisbach (2003), this paper would classify all the variables into four categories well-grounded.

The fist, which is the best original and most important, must be the accounting performance (Hermalin and Weisbach, 1991; Barney, 1986), include profit rate, ROA (return on assets), long-term profitability, sales growth rate and so on. Roland Calori and Philippe Sarnin (1991) select the return on investment ratio (which is a measure of the effective utilization of resources over time), the return on sales ratio (which is a measure of operating efficiency) and the annual variation of the net turnover (which is a nonfinancial variable) to examine the relationship between the organization culture and corporate performance through the field study. What's even more interesting, I think, is that nearly all the studies introduce the accounting performance variables (Ji Li, Kevin Lam, and Gongming Qian, 2001; BAGOZZI, Verbeke, and Gavino, 2003; Fisher \& Alford, 2000, etc.). We would learn from these contributions that the accounting performance variables would never out of date though they are not the unique no longer. And certainly, this paper must account in several variable, such as the profit rate, ROA, and so on.

The second one is some Non-financial Indexes, such as employee satisfaction, custom satisfaction, turnover rate, quality of products/services and some other variables in the organizational Aspects. Besides the finical index, Kaplan and Norton (1992) raised the balanced scorecard to emphases the importance of customer, internal business processes, learning and growth. Bagozzi, Verbeke, and Gavino (2003) divide the corporate performance into the In-role performance and Extra-role performance in their article, Culture Moderates the Self-Regulation of Shame and Its Effects on Performance. The In-role performance includes sales volume, communication effectiveness and relationship building, while the Extra-role performance is made up of courtesy, helping, sportsmanship and civic virtue. It is sure that the nonfinancial variable is the new trend for the performance appraises and related research (Roland Calori and Philippe Sarnin 1991; Meral Elci, Hakan Kitapci \& Alper Ertrk, 2007, etc.). As the development of the employee behavior and the consciousness of social responsibilities, these variables are of equal importance as the accounting variables at least.

Then is the Tobin's Q (note 3) (James Tobin, 1969), which reflects the "value added" of intangible factors such as management and governance (Benjamin E. Hermalin and Michael S. Weisbach, 2003). Unfortunately, there is still no paper using the Tobin' $\mathrm{Q}$ as the measure of the corporate performance. But its importance is worthy of consideration, combing the consideration of the disadvantages of the financial and nonfinancial variables. As suggested by Benjamin E. Hermalin and Michael S. Weisbach (2003), the financial variables cannot reflect the intangible factors' contribution to corporate value, while the nonfinancial variables are difficult to decipher and measure in the form of "value added". Then we can learn from the successful studies in the field of accounting and financial management, such as Hermalin and Weisbach (1991) and Bhagat and Black (2000), which use the boards' independence to predicate the corporate performance, Tobin' Q. Considering the nonfinancial variable in the above analysis, Tobin' $Q$ would make more effects.

The last but not the least is the long-run development, competitive strength, or the long-run stock market performance. To a certain extent, these studies must be based on the time series data or even panel data to follow the subject's long-term performance variation. John P. Kotter and James L. Heskett (1992) did a landmark study of organizational culture and its relationship to the issue of quintessential managerial interest—organizational performance (note 4). They conducted their research in 72 companies across 20 industries in 11 years to follow their corporate performance (include average increment of gross income, the increment of staff quantity, the change of stock price and the variation of corporate net income). These studies would be much more persuasive on the basis of strong financial support and great effort.

By the large, in most studies, the corporate performance is not measured independently but some aspects jointly. For example, Irene Hau-Siu Chow and Shan S. Liu conduct a research on the business strategy, organization culture and 
performance outcomes in China's technology industry. In their research, Knowledge-related outcomes are defined and measured by productivity, research and development capability, products and services quality, and market share. Another example is the study by Torvald Ogaard, Svein Larsen and Einar Marnburg (2005) in which the firm performance is measured by financial performance indicator, service quality indicator, resource utilization indicator and revenue management indicator. All in all, the general recommendation is that no single indicator will give a comprehensive picture of the performance (note 5). Consequently, this paper would put a serious consideration in the variable selection.

\subsection{Organization Culture and Corporate Performance}

As mentioned in the above analysis, there are two directions in the development of organization culture — one is measurement, while the other one is the relationship between the organization culture and corporate performance.

In china, the research on the relationship between the organization culture and corporate performance is much more important, more urgent than any other countries, according to the analysis about the independent thinking in China by Xiao-ping Chen (2008). In the article, the author claims that this mindless premium placed on practices of Western origin can be seen in several trends in Chinese management, one of which is the organization culture. In many cases, the organization culture is just becoming a mere formality without any material meaning, distant from the management. As one of the most important economic entities, Chinese companies have a long way to go in the construction of organization culture. Thus the basic research would be of great significance both for managerial theory and practice.

Since John P. Kotter and James L. Heskett (1992), more and more studies have examined the relationship between the organization culture and corporate performance. Some optimistic researches claim a positive relationship, while there are still some adjective ones, especially considering the culture rigidity (Vries and Miller, 1986; Meyerson and Martin, 1987; Tushman, 1998). In these researches, various methods are applied, such as theoretical study, field study and empirical study and so on. In this paper, we would like to sort out all the researches into several types simply as follows.

The first and the foremost important perspective is the theoretical analysis, which is going to form the theoretical basis for the study of organization culture. In this arena, Barney (1986) and Bernard Arogyaswamy \& Charles M. Byles (1987) are representative scholars. In the research conducted by Barney, the core values (about how to treat employees, customers, suppliers, and others) foster innovativeness and flexibility in firms. And additional, the core values are thought to lead to sustained superior financial performance when they linked with management control. As suggested by Bernard Arogyaswamy and Charles M. Byles, culture is just one of the many variables that could contribute to explaining performance. Moreover, the authors delineated organizational cultures into intracultural and extracultural whose changes are crucial to organizational functioning. In generally, the theoretical research provides us with the rigorous theoretical framework, providing theoretical basis and waiting for verified in the future study.

Then is the research on the direct relationship between organization culture and corporate performance, which is the dominated research front (Dension, 1984; John P. Kotter and James L. Heskett, 1992; Roland Calori and Philippe Sarnin, 1991; Irene Hau-Siu Chow and Shan S. Liu, etc.). Dension established a positive relationship between the high-employee-participation culture and corporate performance (note 6). The study by Kotter and Heskett might be the most typical and paradigmatic study worthy to be discussed carefully. In their study, as suggested by Bluedorn, their finding can be grouped into two categories: a contingency model and a universal model. The contingency model can be summarized as: (1) better performing organizations have strong cultures, but (2) only if the culture fits the organization's environment; furthermore (3) the better performance is sustained over the long-run only if the organization's culture contains change values leading the organization to continually re-adapt, culturally and otherwise, to its environment (note 7). And on the other hand, the universal prescriptive model indicated that for an organization to perform well in the long-term, it must have a culture whose values emphasize care and concern for three constituencies: (1) customers, (2) employees, and (3) stockholders (note 8). Their study would have far-reaching effects both for its idea and methods (linear regression and comparison between the healthy culture companies and unhealthy ones). Roland Calori and Philippe Sarnin conducted the same study as Kotter and Heskett in the French, while Irene Hau-Siu Chow and Shan S. Liu do some extend research in China's technology industry. As a matter of fact, there are numerous studies to examine the basic relationship, such as Aiken, Clarke and Sloane (2002), Schein (1996) and so on. All these studies tell us the importance of organizational culture. And this study will be the start and basis for any newly developed researches.

Some variables (moderators or mediators) in the relationship between the organization culture and corporate performance are worthy of serious consideration, which would be useful to uncover the mechanism in hide. Enterprise strategy (Irene Hau-Siu Chow and Shan S. Liu; Lismen L.M. Chan, Margaret A. Shaffer and Ed Snape, 2004; Richard C. Hoffman, 2007), leadership (Emmanuel Ogbonna and Lloyd C. Harris, 2000; Ken W. Parry \& Sarah B. Proctor-Thomson, 2003; Li Yueh Chen, 2004), HRM styles (M. Khasro Miah and Allan Bird, 2007) and human resource flexibility (Hang-Yue Ngoa and Raymond Loi, 2008), together with organizational commitment (Ulrike de Brentani and 
Elko J. Kleinschmidt, 2004; Li Yueh Chen, 2004) would be meaningful variable in the future study. Furthermore, communication as a Mediator or Moderator of organizational culture's Impact on Public organizational performance is examined by James L. Garnett, Justin Marlowe and Sanjay K. Pandey (2008). In this paper, our writers will give an emphasis on the importance of organizational commitment.

More than that, organization culture can be a moderator or mediator. First, culture is a moderator. As suggested by Bagozzi, Verbeke, and Gavino (2003), the authors investigated how salespeople within an interdependent-based culture (the Philippines) and an independent-based culture (the Netherlands) experience and self-regulate shame. Ji Li, Kevin Lam, and Gongming Qian (2001) do a research to examine how the culture moderates the relationship between the behavior and performance. Second, the organization culture might be a mediator. According to Emmanuel Ogbonna and Lloyd C. Harris (2000), the culture is a full mediator between the leadership style and corporate performance. Then considering the study by Emmanuel Ogbonna and Lloyd C. Harris (2003), the organization culture would be a full mediator as well in the relationship between the individual/team leadership and outcomes. Meanwhile, culture is also a mediator between the enterprise strategy and organization performance (Bernard Arogyaswamy \& Charles M. Byles, 1987). These studies provide a new train of thought in the relationship, and thereby this paper will attempt to test the mechanism behind the organization culture and corporate performance.

Of course, the relationship is not always positively in effect. According to Peter and Waterman (1982), the phenomena that some ever excellent companies go to downfall pass our comprehension. The best explanation would be the "culture rigidity" (Vries and Miller, 1986; Meyerson and Martin, 1987; Tushman, 1998). To be specifically, Christensen (1997) claims that culture antecedents as the summary of old-timey success get in the way of adapting to a new environment rapidly and successfully. Also in the empirical study, Roland Calori and Philippe Sarnin (1991) found that the relations between profitability and the company's cultural attributes were less significant. And other possible question would be taken into account, such as the endogenous problem that organization culture influences the performance while the performance put effect on the organization culture, as examined in Emmanuel Ogbonna and Lloyd C. Harris (2003).

From the foregoing, we have a clear and obvious whole picture on the relationship between the organization culture and corporate performance. (1) The theoretical framework and empirical exploration make great senses, though there is still no consistent conclusion; (2) The mechanism is still in hide, which required more studies to examine possible moderators or mediators. And maybe the organization culture is a moderator or mediator itself; (3) The "culture rigidity" must be accounted into theory and modeling; (4) The endogenous problem should be paid more attention, and the SEM might be a solution; (5) Most of these papers are conducted from case study or field study, which lack of reliability and validity; (6) Nearly no studies based on the time series study to test the stability of the culture and performance. From these points, this paper would account new variable (such as organization commitment) based on the theoretical framework using effective data and analyze methods.

\subsection{Organizational Commitment: Independent Variable, or Moderator, or Mediator?}

\subsubsection{Organizational Commitment}

From Howard S. Becker (1960), commitments come into being when a person, by making a side bet (a consequence of the person's participation in social organizations), links extraneous interests with a consistent line of activity. And from the other perspective, Poter (1976) considered commitment as some emotional beggar, but not something about economy input. Allen \& Meyer (1984) attributed the Becker's commitment as "Continuance Commitment", while they named the Poter's commitment as "Affective Commitment". Then as described by Allen and Meyer (1990, 1991), the organizational commitment can be divided into three different dimensions: Continuance Commitment, Affective Commitment and Normative Commitment.

\section{$<$ Table 1 about here $>$}

As for the measurement of the organizational commitment, Mowday, Steers and Poter (1979) developed a scale named "Organizational Commitment Questionnaire (OCQ)" from the following three dimensions: (1) a strong belief in and acceptance of the organization's goals and values; (2) a willingness to exert considerable effort on behalf of the organization; (3) a strong desire to maintain membership in the organization. And besides, Allen and Meyer (1991, 1993) raised the continuance commitment scale (CCS), normative commitment scale (NCS), and the affective commitment scale (ACS), which is combined widely used.

The organizational commitment results from some antecedent variables (such as personal character; age; experience, etc.) and can be used to predicate some phenomenon (such as turnover rate; attendance; and job performance and so on), according to the research by Mowday (1982), Steers (1977), and Allen (1990, 1991, 1997, 2001, 2003). This paper would like to select the organizational commitment to test the mechanism in the relationship between the organization culture and corporate performance. 


\subsubsection{Organizational Commitment and Organization Culture}

Many researchers have supported the importance of culture for organizational commitment (Li Yueh Chen, 2004). Brewer (1993) suggested that a bureaucratic working environment often results in negative employee commitment, whereas, a supportive working environment results in greater employee commitment and involvement. Li Yueh Chen (2004) studied the relationship between the leadership and organizational commitment moderated by the organization culture. Ulrike de Brentani and Elko J. Kleinschmidt (2004) used the interactions of organization culture and commitment to predicate the corporate performance. Though there is still no clear relationship between the culture and organizational commitment, they are usually interplayed together. And in this paper, we are interest in these interactions to mine the mechanism behind the relationship between the organization culture and corporate performance.

\subsubsection{Organizational Commitment and Corporate Performance}

According to the measurement of corporate performance, the organizational commitment is not like to predicate the accounting performance directly. So there would be two directions from the relationship between the organizational commitment and corporate performance: (1) Considering some nonfinancial variables, such as job satisfaction (Tser-Yieth Chen, Shiuh-Nan Hwang and York Liu, 2009), employee trust (Tser-Yieth Chen, Shiuh-Nan Hwang and York Liu, 2009), procedure justice (Etty Murwaningsari, 2008), the organizational commitment might have a direct relations with them; (2) The organizational commitment often plays a role as a moderator or a mediator. Li Yueh Chen (2004) verified the commitment as a mediator in the relationship between the leadership and corporate performance. Etty Murwaningsari (2008) defined the organizational commitment as a moderator in the relationship between budgetary participation and management performance. And Tser-Yieth Chen, Shiuh-Nan Hwang and York Liu (2009) considered commitment as moderators of the effects of idealized and consideration leadership on voluntary performance.

From the brief history of organizational commitment, and limited researches on the relationship between the organizational commitment and organization culture/corporate performance, we cannot draw a clear picture to present these relationships. And accounting into the complexity, this paper is going to examine the relationship between the organization culture and corporate performance, together with organizational commitment as a moderator or a mediator.

\section{Discussion: An Ideational Model}

From all the studies, we can get an ideational model (see the figure 2). From the framework, we would like to discuss the organization culture from the following three perspectives:

\section{$<$ Figure 2 about here $>$}

First, from the perspective of the direct relationship between the organization leadership and corporate performance, we would like to give some new suggestion: (1) the study from a new perspective, maybe about "fitness"; (2) the new measure of organization culture and corporate performance; (3) the new statistic methods, such like panel data and so on.

Secondly, from the perspective of the dependent variable, there are more and more research that focus on the study of nonfinancial variables. For example, we care about the job satisfaction, justice, turnover rate, organization citizenship behavior and motivation and so on instead of corporate performance.

And thirdly, we would like to mine the mechanism in hide, maybe the moderator or mediator and so on. These studies would be a useful supplement for the traditional study.

All in all, the study about the organization culture would be much more meaningful.

\section{References}

Abraham, Y. Nahm, M. A. V. X. (2004). The Impact of Organizational Culture on Time-Based Manufacturing \& Performance: Decision Sciences, v. 35, p. 579-607. http://dx.doi.org/10.1111/j.1540-5915.2004.02660.x

Atkinson, H, Brown, J. B. (2001). Differences between managers \& line employees in a quality management environment. International Journal of Contemporary Hospitality Management, v.13:128-35. http://dx.doi.org/10.1108/09596110110388918

Barney, J. B. (1986). Organization culture: can it be a source of sustained competitive advantage?: Academy of Management Review, v. 11, p. 656-665.

Barney, J., \& Wright, P. M. (1998). On becoming a strategic partner: the role of human resources in gaining competitive $\begin{array}{lllll}\text { advantage. Human } & \text { Resource } & \text { Management, } & \text { V.37(1): } & 31-46\end{array}$ http://dx.doi.org/10.1002/(SICI)1099-050X(199821)37:1<31::AID-HRM4>3.0.CO;2-W 
Becker, B. \& Gerhart, B. (1996). The impact of human resources management on organizational performance: progress \& prospects. Academy of management journal, V.39:779-801 http://dx.doi.org/10.2307/256712

Becker, H. S. (1960). Notes on the concept of commitment. The American Journal of Sociology, v. 66, p. 32-40. http://dx.doi.org/10.1086/222820

Beliz Ozorhon, D. A. I. D. (2008). Implications of Culture in the Performance of International Construction Joint Ventures: Journal Of Construction Engineering \& Management, p. 361-370. http://dx.doi.org/10.1061/(ASCE)0733-9364(2008)134:5(361)

Bernar Arogyaswamy, C. M. B. (1987). Organization Culture: internal \& external fits: Journal of Management, v. 13, p. 647-659. http://dx.doi.org/10.1177/014920638701300406

Bird, M. K. M. A. (2007). The impact of culture on HRM styles \& firm performance: evidence from Japanese parents, Japanese subsidiaries/joint ventures \& South Asian local companies: The International Journal of Human Resource Management, v. 18, p. 908-923. http://dx.doi.org/10.1080/09585190701249537

Chen, L. Y. (2004). Examining the Effect of Organization Culture \& Leadership Behaviors on organizational commitment, job satisfaction, \& job performance at small \& middle-sized firms of Taiwan: The Journal of American Academy of Business, p. 432-438.

Denison, D. R. \& Mishra A. K.. (1995). Toward a theory of organizational culture \& effectiveness. Organization Science, v.6(2): 204-223 http://dx.doi.org/10.1287/orsc.6.2.204

Edgar H. Schein. (1985). The role of the founder in creating organizational culture. Organizational Dynamics, V.2, p. $13-28$

George, G. \& Gordon, N. D. T. (1992). PREDICTING CORPORATE PERFORMANCE FROM ORGANIZATIONAL CULTURE: Journal of Management Studies, v. 29.

Harris, E. O. A. L. (2000). leadership style, organization culture,\& performance: empirical evidence from UK companies: The International Journal of Human Resource Management, v. 11, p. 766-788. http://dx.doi.org/10.1080/09585190050075114

Heydemann, S. (2008). Institutions \& Economic Performance :The Use \& Abuse of Culture in New Institutional Economics: St Comp Int, p. 27-52.

Hoffman, R. C. (2007). The Strategic Planning Process \& Performance Relationship: Does Culture Matter?: Journal of Business Strategies, v. 24.

Hofstede, G. (1990). Measuring organizational culture: A qualitative \& quantitative study across twenty cases: Administrative Science Quarterly, v. 35, p. 286-317. http://dx.doi.org/10.2307/2393392

Irene Hau-Siu Chow, S. S. L. (2007). Business Strategy, Organizational Culture, \& Performance Outcomes in China's Technology Industry: Human Resource Planning, v. 30, p. 47-56.

James, L. \& Garnett, J. M. S. K. (2008). penetrating the Performance Predicament: Communication as a Mediator or Moderator of Organizational Culture's Impact on Public Organizational Performance.: Public Administration Review.

Jay Prakash Mulki, W. B. L. G. (2008). Workplace Isolation, Salesperson Commitment, \& Job Performance: Journal of personal selling \& sales management, v. 18, p. 67-78. http://dx.doi.org/10.2753/PSS0885-3134280105

Ji Li, K. L. G. Q. (2001). Does Culture Affect Behavior \& Performance of Firms? The Case of Joint Ventures in China: journal of International Business Studies, v. 32, p. 115-131.

Joan, F. \& Brett, W. L. C. J. (1995). A Moderator Of The Relationship Between Organizational Commitment \& Performance.: Academy of management journal, v. 38, p. 261-271.

John, P. \& Meyer, N. J. A. (1991). Three-Component Conceptualization Of Organizational Commitment: Human Resource Management Review, v. 1, p. 61-89.

Ken, W. Parry, S. B. P. (2003). Leadership, culture \& performance: The case of the New Zeal\& public sector: Journal of Change Management, v. 3, p. 376-399.

Kibeom Lee, N. J. A. J. (2001). The Three-Component Model of Organizational Commitment: An Application to South Korea: Applied Psychology: An International Review, v. 50, p. 596-614.

Kotter John, P. \& Heskett. (1992). Corporate culture \& performance. New York: A Division of MacMillan 
Larry, W. Hunter, S. M. B. T. (2007). Effects of stress, commitment, feeling the heat: effects of stress, commitment, \& job experience on job performance: academy of management journal, v. 50, p. 953-968. http://dx.doi.org/10.5465/amj.2007.26279227

Lismen, L. M. \& Chan, M. A. S. A. (2004). The impact of organizational culture, competitive strategy \& human resource management practices on firm performance.: The International Journal of Human Resource Management, v. 15, p. 17-35. http://dx.doi.org/10.1080/0958519032000157320

Loi, H. N. A. R. (2008). Human resource flexibility, organizational culture \& firm performance: an investigation of multinational firms in HongKong: The International Journal of Human Resource Management, v. 19, p. 1654-1666. http://dx.doi.org/10.1080/09585190802295082

Man Zhang, P. T. (2007). Organizational Culture, Information Technology Capability, \& Performance: The case of born global firms: THE MULTINATIONAL BUSINESS REVIEW, v. 15, p. 43-77. http://dx.doi.org/10.1108/1525383X200700012

Meral Elci, H. K. A. E. (2007). Effects of Quality Culture \& Corporate Ethical Values on Employee Work Attitudes \& Job Performance in Turkey An Integrative Approach.: Total Quality Management, v. 18, p. 285-302. http://dx.doi.org/10.1080/14783360601152475

Moliy Inhofe Rapert, D. L. T. S. (1996). enhancing functional \& organizational performance via strategic consensus \& commitment: Journal of Strategic Marketing, p. 193-205. http://dx.doi.org/10.1080/09652549600000004

Murwaningsari, E. (2008). The Role Of Organizational Commitment \& Procedural Justice In Moderating The Relationship Between Budgetary Participation \& Managerial Performance: Gadjah Mada International Journal of Business, v. 10, p. 185-210.

Natalie, J. \& Allen, J. P. M. (1990). the measurement \& antecedents of affective, continuance \& normative commitment to the organization: Journal of Occupational psychology, p. 1-18.

Nugent, J. B. (2008). "Institutions \& Economic Performance: The Use \& Abuse of Culture in New Institutional Economics": A response to Heydemann: St Comp Int, p. 206-217.

Pleggenkuhle-Miles, M. W. P. A. (2009). Current debates in global strategy: International Journal of Management Reviews, v. 11, p. 51-68. http://dx.doi.org/10.1111/j.1468-2370.2008.00249.x

Quinn, R. E. \& Spreitzer, G. M. (1991). The psychometrics of the competing values culture instrument \& an analysis of the impact of organizational culture on quality of life. Research in Organizational changes \& development. V.5: $115-142$

Reilly, C. O. (1989). Corporation, Culture, \& Commitment: Motivation \& Social Control in Organization: California Management Review.

Richard Jr., P. \& Bagozzi, W. V. J. C. (2003). Culture Moderates the Self-Regulation of Shame \& Its Effects on Performance: Journal of Applied Psychology, v. 88, p. 219-233. http://dx.doi.org/10.1037/0021-9010.88.2.219

Robert, R. \& Sinclair, J. S. T. C. (2005). Performance Differences Among Four Organizational Commitment Profiles: Journal of Applied Psychology, v. 90, p. 1280-1287. http://dx.doi.org/10.1037/0021-9010.90.6.1280

Roland Calori, P. S. (1991). Corporate Culture \& Economic Performance: A French Study: Organization studies, v. 12, p. 049-074.

Santora, J. C. (2009). Quality Management \& Manufacturing Performance: Does Success Depend on Firm Culture?: Academy of Management Perspectives.

Schein, E. H. (1984). coming to a new awareness of organizational culture: Sloan Management Review, v. 25, p. 3-16.

Schein, E. H. (1992). Organizational Culture \& Leadership, San Francisco, CA: Jossey-Bass Publishers.

Sorensen, J. B. (2002). the strength of corporate culture \& the reliability of firm performance: Administrative Science Quarterly, p. 70-91. http://dx.doi.org/10.2307/3094891

Stephen, J. \& Deery, R. D. I. (1999). The impact of industrial relations climate, organizational commitment, \& union loyalty on organizational performance: a longitudinal study: academy of management proceedings.

Thomas, P. \& Robert, W. (1988). In search of Excellence. Grand Central Pub

Torvald, S. L. A. E. (2005). Organizational culture \& performance- evidence from the fast food restaurant industry.: Food Service Technology, p. 23-34. 
Tser-Yieth Chen, S. H. Y. L. (2009). Employee Trust, Commitment \& Satisfaction as Moderators of the Effects of Idealized \& Consideration Leadership on Voluntary Performance: A structural Equation Investigation: International Journal of Management, v. 26, p. 127-141.

Tullar, T. W. M. A. (1986). Performance Appraisal as an Organizational Intervention A Case Study of Appraisals as a Unifier of Corporate Cultures: American Business Review, p. 50-58.

Ulrike De Brentani, E. J. K. (2004). Corporate Culture \& Commitment: Impact on Performance of International New Product Development Programs: Product Innovation Management, p. 309-333.

Very, S. T. A. P. (2006). The Culture-Performance Relationship in M\&A: From Yes/No to How: British Journal of Management, v. 17, p. 31-48. http://dx.doi.org/10.1111/j.1467-8551.2006.00477.x

Zuckeiman, A. (2002). Strong Corporate Cultures \& Firm Performance Are There Tradeoffs: Academy of Management Executive.

Notes

Note 1. Schein, E. H. Organizational Culture and Leadership, San Francisco, CA: Jossey-Bass Publishers, 1992

Note 2. Thomas Peters \& Robert Waterman. In search of Excellence. Grand Central Pub, 1988 Note 3. Tobin' Q Rate= $\frac{\text { Tota market: walue of flrm }}{\text { Total asset value }}$

Note 4. Allen C. Bluedorn. Review of Corporate Culture and Performance.

Note 5. Atkinson H, Brown JB. Differences between managers and line employees in a quality management environment. International Journal of Contemporary Hospitality Management, 2001:13:128-35.

Note 6. Dension. Bring corporate culture to the bottom line. Organizational Dynamics, 1984

Note 7. Allen C. Bluedorn. Review of Corporate Culture and Performance.

Note 8. Allen C. Bluedorn. Review of Corporate Culture and Performance.

Table 1. The three-dimensional model of organizational commitment

\begin{tabular}{|c|c|}
\hline Dimension & Definition \\
\hline Continuance Commitment & recognition of the costs associated with leaving the organization \\
\hline Affective Commitment & emotional attachment to the organization \\
\hline Normative Commitment & perceived obligation to remain with the organization \\
\hline
\end{tabular}

Source: Kibeom Lee, Natalie J. Allen, John P. Meyer, and Kyung-Yong Rhee, 2001 


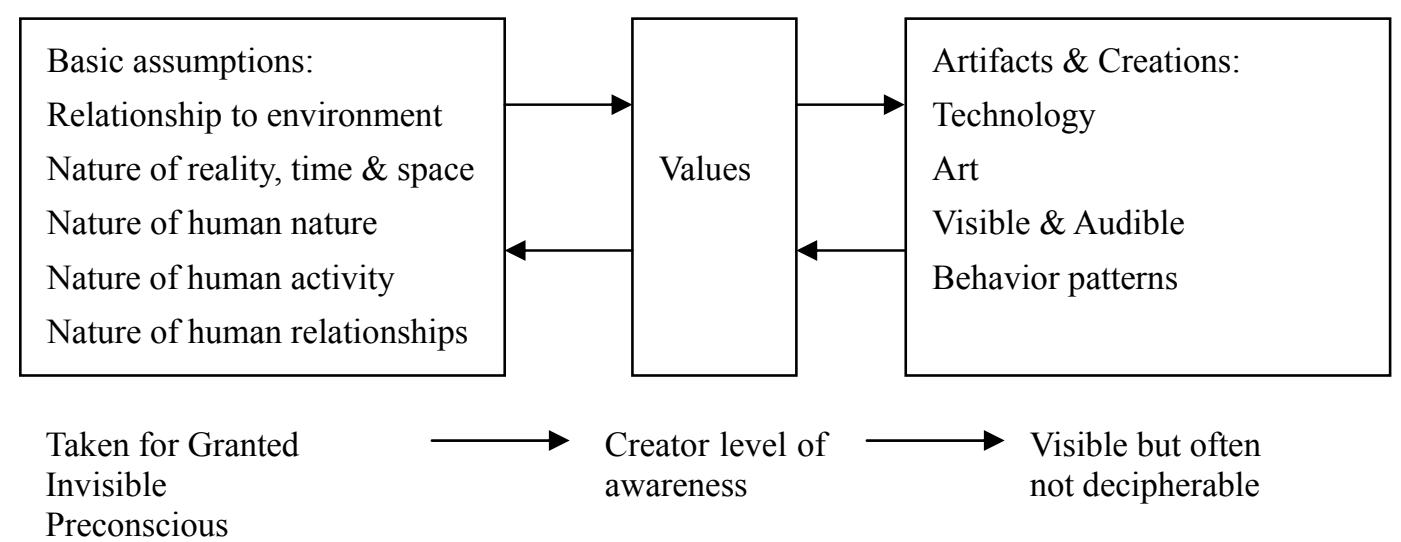

Figure 1. The level of cultures and their interactions (Schein, 1982)

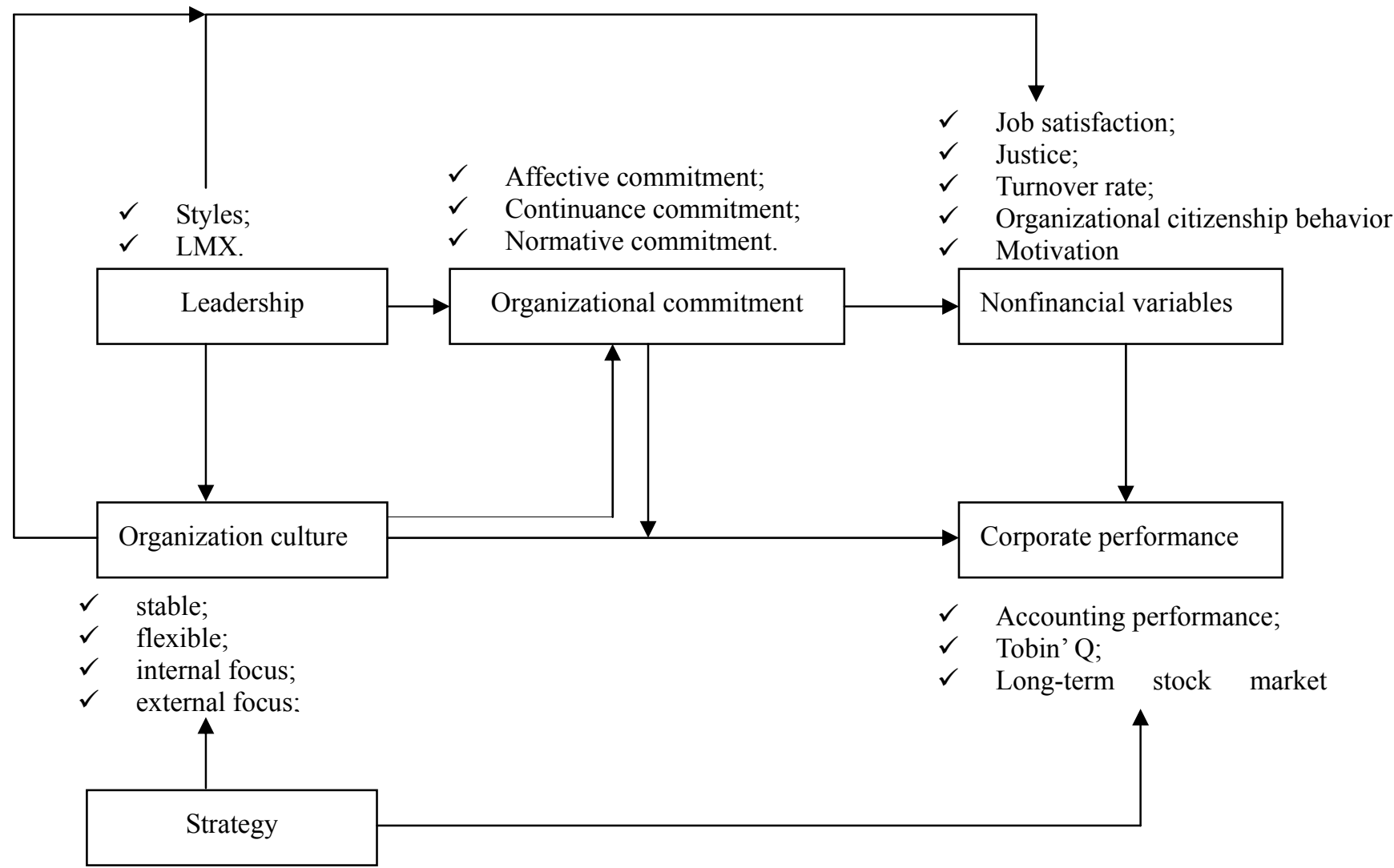

Figure2. An ideational model 